\title{
Evolving concept of diet from ethnicity to modernity
}

\author{
Senjuti Saha ${ }^{1}$, Raghubibha Sen ${ }^{2, *}$, Rama Das ${ }^{3}$ \\ ${ }^{1}$ Part-time Lecturer, ${ }^{2}$ Ex Medical Officer, ${ }^{3}$ Assistant Professor, ${ }^{1}$ Mankar College, Mankar, West Bengal, ${ }^{2}$ State Ayurvedic \\ Hospital, Tripura, ${ }^{3}$ Barrackpore Rastraguru Surendranath College, Barrackpore, West Bengal, India
}

*Corresponding Author:

Email: raghubibha@gmail.com

\begin{abstract}
"Ahara" is considered to be an important term in Ayurveda and it helps to prevent and manage a wide range of disorders like seeds of barley, wheat, beans are prescribed for diabetes mellitus (madhumeha) etc. The food with incompatible or contradictory qualities has poisonous effect on the body which aggravates various disorders. According to ayurveda there are some dietetic variations according to season, and different tastes also possess specific biological activity affecting physiology and nutritional impact. The recipes for clinical nutrition portrays several form of diets with clinical properties, which certainly play a vital role in prevention and management of diseases.But now our today's diet is drastically changed. The objectives of this review is to summarize traditional foods and their dietary guidelines which are prescribed in Ayurveda and to investigate how our diet concept transfigure from ethnicity to modernity. This study establishes that to survive from present health maladies we have to take our coumtry's traditional ayurvedic system which needs to serve as inspiration for today's society.
\end{abstract}

Keywords: Seasonal dietetics, Incompatible diet, Interventions, Disease specific diet, Junk food.

\section{Introduction}

Centuries and centuries ago, cavemen ate from the earth- fresh vegetables, fruits, other natural and unprocessed, newly-grown, sound food. After the cave age our country has reveal the dietetics in Ayurvedic practices i.e. traditional foods and their dietary guidelines are prescribed in Ayurveda. ${ }^{4}$ The term Ayurveda consists of two words - ayu (life) and veda (knowledge), thus, deals with various angle related to health and wellbeing in their diverse aspects, such as happy life, to uphold happiness, and longevity. ${ }^{5}$ There is so much resemblance to ayurvedic dietetics and traditional foods that many of the traditional health foods in India can be called ayurvedic foods. Indian traditional foods are also recognized as functional foods because of the presence of functional components such as body-healing chemicals, antioxidants, dietary fibres, and probiotics. These functional molecules help in weight management, and blood sugar level balance and support immunity of the body. ${ }^{1}$ Use of Hita Ahara (wholesome diet) supports health and longevity and Ahita Ahara (unwholesome diet) leads to manifestation of different disorders.

\section{Food practices according to Indian old literature}

Dating back to Indian civilizations and Indian old literature, namely Bhagavadgita, Ramayana, and
Manusmriti, every community that lived in India had a dictinct and separate food belief system. Most of these, however, have been inspired by Aryan beliefs and practices. The four Vedas, namely Rigveda, Samaveda,Yajurveda, and Atharva veda, mark out different cereal grains and their use in our daily life. Barley became the Aryans' introductory staple food, and is also mentioned in the Rigveda. The most liked lentils used were red lentils, green lentils, and black lentils. "Apupa" is a form of cake made by frying barley. Kichadi prepared from rice together with lentils mostly consumed by Aryans. The literature of Buddhists and Jains reveal the popularity of rice and its gruel. ${ }^{1}$

\section{Classified of food material}

Aryans broadly classified food materials on the basis of their nature and use such as: Sukadhanya(cereals); Samidhanya (pulses); Phala (fruits) ;Shakna (vegetables); Payovarga (milk products); Madhyavarga (alcoholic beverages); Mamasavarga (animal products); Gorasavarga (class of milk and milk products); Ikshuvikara Varga (class of sugarcane and its products); Kritanyavarga ( manda, peya, vilepi); Aharapoyogivarga (oil, spices, condiments) (Table 1). ${ }^{1}$

Table 1: Classified food material

\begin{tabular}{|l|l|l|l|}
\hline $\begin{array}{c}\text { Name of the } \\
\text { Classified food } \\
\text { group }\end{array}$ & \multicolumn{1}{|c|}{$\begin{array}{c}\text { Included food } \\
\text { material }\end{array}$} & \multicolumn{1}{|c|}{ Nutrients } & \multicolumn{1}{|c|}{ Beneficial impacts on health } \\
\hline $\begin{array}{l}\text { Sukadhanya } \\
\text { (class of corns and } \\
\text { cereals) }\end{array}$ & $\begin{array}{l}\text { Different varieties } \\
\text { of rice. Red variety } \\
\text { (Rakta Shali) is best }\end{array}$ & $\begin{array}{l}\text { Carbohydrate; } \\
\text { Thiamine etc. }\end{array}$ & $\begin{array}{l}\text { Barley is indicated in Diabetes; Obesity; } \\
\text { Injuries; Hyperension; Cholesterolemia; } \\
\text { Slow stomach emptying. }\end{array}$ \\
\hline
\end{tabular}

IP Journal Of Nutrition, Metabolism And Health Science, July-September, 2018; 1(2):8-15 


\begin{tabular}{|c|c|c|c|}
\hline & $\begin{array}{l}\text { among the rice } \\
\text { varieties; Wheat; } \\
\text { Barley etc. }\end{array}$ & & \\
\hline $\begin{array}{l}\text { Simbidhanya or } \\
\text { Shamidhanya } \\
\text { (class of legumes } \\
\text { and pulses) }\end{array}$ & $\begin{array}{l}\text { Green gram, } \\
\text { Back gram, } \\
\text { Horse gram, } \\
\text { Tila etc. }\end{array}$ & $\begin{array}{l}\text { Vitamin E, } \\
\text { Copper, } \\
\text { Black gram } \\
\text { Contains } \\
\text { Potassium etc. }\end{array}$ & $\begin{array}{l}\text { 1. Pulses cures Cardiovascular disease; } \\
\text { Obesity } \\
\text { 2. Horsegram is curative in urinary } \\
\text { calculi; bowel haemorrhage } \\
\text { 3. Black gram reduce hypertension }\end{array}$ \\
\hline $\begin{array}{l}\text { Mamsavarga } \\
\text { (Flesh food) }\end{array}$ & $\begin{array}{l}\text { Beef; Fish; Chicken; } \\
\text { Mutton, etc. }\end{array}$ & $\begin{array}{l}\text { Protein, Iron, } \\
\text { Vitamin-B12. }\end{array}$ & $\begin{array}{l}\text { Beef is curative in Rhinitis; Irregular } \\
\text { fever; Wasting of muscles. }\end{array}$ \\
\hline $\begin{array}{l}\text { Shakna } \\
\text { (vegetables) }\end{array}$ & $\begin{array}{l}\text { Bottle gourd, } \\
\text { Waxgourd, } \\
\text { Cucumber, Radish, } \\
\text { Cabbage etc. }\end{array}$ & $\begin{array}{l}\text { Green-leafy } \\
\text { vegetables are } \\
\text { rich in Potassium } \\
\text { Radishes are a } \\
\text { very good source } \\
\text { of Vitamin C, } \\
\text { Folate, Fibre, } \\
\text { Riboflavin, and } \\
\text { Potassium. }\end{array}$ & $\begin{array}{l}\text { 1. Bottle gourd is recommended for } \\
\text { Weight-control programs } \\
\text { 2. Cucumber is Diuretic } \\
\text { 3. Waxgourd helps in the elimination } \\
\text { of urine and faeces; management of } \\
\text { Benign Prostatic } \\
\text { 4. Hyperplasia(BPH) } \\
\text { 5. Snakegourd is beneficial to Ulcers, } \\
\text { 6. Radishes are effective in } \\
\text { 7. Colorectal cancer; lower } \\
\text { Cholesterol; manage Diabetes; } \\
\text { regulate Blood pressure } \\
\text { 8. Hummingbird flower is especially } \\
\text { beneficial in Night blindness; Bone } \\
\text { strengthening. }\end{array}$ \\
\hline $\begin{array}{l}\text { Phala } \\
\text { (Fruits) }\end{array}$ & $\begin{array}{l}\text { Pomegranates } \\
\text { Amalaki, Guava, } \\
\text { Apple, Dates, } \\
\text { Coconut, Mango, } \\
\text { Almond etc. }\end{array}$ & $\begin{array}{l}\text { Dates are rich } \\
\text { sources of Fibre, } \\
\text { Copper and } \\
\text { Potassium. } \\
\text { Almonds are a } \\
\text { very good sources } \\
\text { of Vitamin E, } \\
\text { Manganese }\end{array}$ & $\begin{array}{l}\text { 1. Pomegranates might help prevent } \\
\text { Heart disease; treat Jaundice; } \\
\text { Diarrhoea } \\
\text { 2. Amlaki is beneficial to Eye sight; } \\
\text { Diabetes } \\
\text { 3. Grapes has been found to play a } \\
\text { protective role against Colon cancer; } \\
\text { Prostate cancer; Coronary heart } \\
\text { disease(CHD) } \\
\text { 4. degenerative nerve disease } \\
\text { 5. Alzheimer's disease } \\
\text { 6. Mango has been found to play a } \\
\text { protective role against Asthma; } \\
\text { 7. Prostate cancer } \\
\text { 8. Dates are proves curative in cases of } \\
\text { Haemoptysis. }\end{array}$ \\
\hline Jalavarga & $\begin{array}{l}\text { Both cold water and } \\
\text { hot water. }\end{array}$ & $\begin{array}{l}\text { Cold water is } \\
\text { beneficial in hot } \\
\text { seasons and in } \\
\text { burning sensation } \\
\text { of the body. }\end{array}$ & $\begin{array}{l}\text { Warm water is Appetizing; Diuretic and } \\
\text { Febrifuge. The use of water boiled and } \\
\text { subsequently cooled down is } \\
\text { recommended in Dysentery,Burning of } \\
\text { the skin, Haemoptysis }\end{array}$ \\
\hline Gorasavarga & $\begin{array}{l}\text { Milk of Buffalo, } \\
\text { Camel, Mare, Ass, } \\
\text { Elephant, Sheep and } \\
\text { Human, } \quad \text { Curd, } \\
\text { Buttermilk and } \\
\text { Ghee etc. }\end{array}$ & $\begin{array}{l}\text { Calcium, Protein, } \\
\text { Fat, Vitamin.A. }\end{array}$ & $\begin{array}{l}\text { 1. The milk of buffalo is useful in } \\
\text { 2. persons suffering from Insomnia. } \\
\text { 3. Goats milk is especially useful in } \\
\text { persons suffering from Phthisis. } \\
\text { 4. Human milk is useful in Eye } \\
\text { diseases and Raktapitta. } \\
\text { 5. Curd (Dadhi) is Appetizer, } \\
\text { Stimulant,Aphrodisiac, and is useful } \\
\text { in Nasal catarrh, Diarrhoea. } \\
\text { 6. Ghritam (clarified butter) promotes } \\
\text { Memory, Intellect and specially }\end{array}$ \\
\hline
\end{tabular}




\begin{tabular}{|c|c|c|c|}
\hline & & & $\begin{array}{l}\text { curative in Eye diseases like } \\
\text { Cataract }\end{array}$ \\
\hline Madyavarga & $\begin{array}{l}84 \text { types of } \\
\text { Alcoholic products }\end{array}$ & $\begin{array}{l}\text { Starch, } \\
\text { Carbohydrate, } \\
\text { Fluoride }\end{array}$ & $\begin{array}{l}\text { 1. It promotes Confidence, Energy, } \\
\text { Intelligence, Strength and it works } \\
\text { as Elixir. } \\
\text { 2. Antioxidants in red wine called } \\
\text { Polyphenols may help prevent } \\
\text { damage to blood vessels, reduces } \\
\text { Low-Density Lipoprotein (LDL), } \\
\text { Cholesterol and prevents blood clots } \\
\text { and is a good Appetizer. }\end{array}$ \\
\hline Ikshuvarga & $\begin{array}{l}\begin{array}{l}\text { Sugarcane } \\
\text { Asphanita } \\
\text { cane juice), Gudsts } \\
\text { (sugar }\end{array} \\
\text { Matsyandika } \\
\text { (refined sugar) } \\
\text { Khanda(superior } \\
\text { variety of sugar) and } \\
\text { Sarkara (crystallized } \\
\text { sugar) }\end{array}$ & $\begin{array}{l}\text { The most } \\
\text { common nutrients } \\
\text { found in Honey } \\
\text { are Vitamin B6, } \\
\text { Niacin, Thiamine, } \\
\text { Pantothenic acid, } \\
\text { and Riboflavin } \\
\text { etc. }\end{array}$ & $\begin{array}{l}\text { 1. Sugarcane is Spermatopoetic and } \\
\text { Diuretic. } \\
\text { 2. Guda acts as Demulcent and purifier } \\
\text { of blood and urine. } \\
\text { 3. Sugar is Aphrodisiac and Unctuous; } \\
\text { useful in thirst and burning } \\
\text { sensation. } \\
\text { 4. Honey acts as a purifying and } \\
\text { healing agent in respect of Ulcers } \\
\text { and Eyes and is Aphrodisiac. }\end{array}$ \\
\hline $\begin{array}{l}\text { Kritanna varga } \\
\text { (class of cooked } \\
\text { food) }\end{array}$ & $\begin{array}{l}\text { Manda } \\
\text { water), Peya (thin } \\
\text { gruel), } \\
\text { Yavagu (thick gruel) } \\
\text { and Odana (boiled } \\
\text { rice) }\end{array}$ & $\begin{array}{l}\text { Carbohydrates } \\
\text { Starch etc. }\end{array}$ & $\begin{array}{l}\text { 1. Manda stimulates the power of } \\
\text { digestion and facilitates the } \\
\text { downward movement of flatus. } \\
\text { 2. Peya alleviates hunger, thirst, } \\
\text { depression, weakness, Abdominal } \\
\text { diseases and Fever. } \\
\text { 3. Vilepi is Refreshing, Bowel binding, } \\
\text { light and Cardio tonic. } \\
\text { 4he Soup (Yusa) of Masura or } \\
\text { Mudga or Kulatha is specially } \\
\text { recommended in Nervous diseases; } \\
\text { Asthma, Cough, Piles etc. }\end{array}$ \\
\hline Aharaupayogivarga & $\begin{array}{l}\text { This class contains } \\
\text { different types of } \\
\text { Oils, daily useful } \\
\text { dietary supplements } \\
\text { like Pippali, Shunthi } \\
\text { etc, different types } \\
\text { of Salts, etc. }\end{array}$ & $\begin{array}{l}\text { Fat, cholesterol, } \\
\text { iron etc }\end{array}$ & $\begin{array}{l}\text { 1. Mustard oil cures Itching and } \\
\text { Urticaria } \\
\text { 2. Ginger is used for treating } \\
\text { Indigestion, Flatulence, Colic, } \\
\text { Vomit, Stomach spasm, Cold, } \\
\text { Cough and Asthma. } \\
\text { 3. Hingu (Asafoetida) relieves Colic } \\
\text { pain, Indigestion and suppression of } \\
\text { stool } \\
\text { 4. Cumin promotes Digestion and } \\
\text { relieves Diarrhoea. } \\
\text { 5. Black pepper is a Stimulant, } \\
\text { Decongestant, Expectorant and } \\
\text { Digests fat. } \\
\text { 6. Garlic cures Infections, useful in } \\
\text { Skin Diseases. } \\
\text { 7. Turmeric is a powerful Anti- } \\
\text { inflammatory and Antiseptic, useful } \\
\text { for Bronchial asthma, Chronic } \\
\text { cough. It has an Anticancer } \\
\text { properties, keeping the blood thin. } \\
\text { 8. Rock salt is promoter of Digestion, } \\
\text { Aphrodisiac, conducive for } \\
\text { Eyesight } 1,6\end{array}$ \\
\hline
\end{tabular}


Seasonal dietetics: Seasonal climate and atmosphere have definite effect upon human digestion. Hence, ayurveda has advised some dietetic variations according to season (Table 2). ${ }^{3}$

Table 2: Seasonal Dietetics

\begin{tabular}{|l|l|l|l|}
\hline Season & Reccommended food type & \multicolumn{1}{|c|}{ Prescribed food } & \multicolumn{1}{|c|}{ Rejected food } \\
\hline Spring & $\begin{array}{l}\text { Easy for Digestion, bitter, } \\
\text { hot and astringent, light } \\
\text { diet are advised }\end{array}$ & $\begin{array}{l}\text { Wheat, Barley, Honey and } \\
\text { Water, Fruits like Mango, } \\
\text { Jackfruit and Flesh of Forest } \\
\text { Animals are advised }\end{array}$ & $\begin{array}{l}\text { Salty, sour and sweet, } \\
\text { hay unctuous diets and } \\
\text { sleep should be } \\
\text { avoided }\end{array}$ \\
\hline Summer & $\begin{array}{l}\text { Cold, liquid, sweet and oily } \\
\text { diet is recommended. }\end{array}$ & $\begin{array}{l}\text { Rice, Milk, Sugar, Ghee, } \\
\text { Grapes, Coconut water, Meat } \\
\text { of forest animal is strongly } \\
\text { prescribed. }\end{array}$ & $\begin{array}{l}\text { Hot, salty, sour, spicy, } \\
\text { pungent diet should be } \\
\text { avoided. }\end{array}$ \\
\hline Rainy season & $\begin{array}{l}\text { Sweet, sour, salty food and } \\
\text { beverages are preserved. } \\
\text { The food must be hot, dry, } \\
\text { fatty and easily digestible. }\end{array}$ & $\begin{array}{l}\text { Old barley, Wheat, Red rice } \\
\text { along with Meat of arid } \\
\text { animals and Vegetable soup } \\
\text { and Mutton soups are advised }\end{array}$ & \\
\hline Winter & $\begin{array}{l}\text { Fatty, sweet, sour and salty } \\
\text { food. }\end{array}$ & $\begin{array}{l}\text { Milk, Sugar cane, Rice, Oils } \\
\text { and Fats are advised }\end{array}$ \\
\hline Autumn & $\begin{array}{l}\text { Bitter, sweet, pungent } \\
\text { dominant,light, and cold } \\
\text { food and beverage. }\end{array}$ & $\begin{array}{l}\text { Rice, Green gram, Sugar, } \\
\text { Amla, Snake gourd, Honey, } \\
\text { Meat of Arid animal }\end{array}$ \\
\hline
\end{tabular}

Incompatible diet (viruddha ahara) and toxicology: The food with incompatible or contradictory qualities has poisonous effect on the body which aggravates various disorders and cause different allergic and hypersensitive reactions like: Kandu (itching); Kushta (skin disorders); Kotha (allergic skin lesions); Pidaka (boils); Charmadala (callosity); can be comparable to photoallergic and phototoxic reactions caused by industrial hydrocarbons, tars etc. which emits considerable UV radiation of different wave lengths. Charaka has highlighted about incompatible diet initiates various diseases viz: Gulma (Lump), Fever, Allergic dermatitis, Eczema, Abscess and other Skin diseases. It also pull down strength, vigour, memory, immunity etc. which intern leading to, the diseases like amavata (rheumatoid arthritis); madhumeha (diabetes); sthoulya (obesity); arbuda (cancer); yakrit vriddhi (liver diseases); nidranasha (insomnia); chittodvega (anxiety neurosis) and tamaka swasa (bronchial asthma) are highly prevalent and are labeled as lifestyle disorders. Charaka mentions that the intake of incompatable diet is liable to the causation of sterility; blindness; visarpa (herpes); udara (ascites); insanity; fistula in ano; coma or fainting; intoxication; abdominal distention; stiffness in neck; varieties of anaemia; indigestions; various skin disorders; diseases of intestines; gastritis; fever; rhinitis; infertility. ${ }^{1}$

\footnotetext{
The dietary incompatibility is of eighteen types, which are as follows:

1. Desha viruddha (contrary to climate)

2. Kala viruddha (contrary to season)

3. Agni viruddha (contrary to digestive power)

4. Matra viruddha (contrary to measure)
}

5. Satmya viruddha (contrary to adaptability)

6. Dosh viruddha (contrary to body humors)

7. Sanskara viruddha (contrary to processing)

8. Virya viruddha (contrary to potency)

9. Koshtha viruddha (contrary to bowel habits)

10. Avastha viruddha (contrary to patient's state)

11. Krama viruddha (contrary to order of eating)

12. Parihara viruddha (contrary to restrictions)

13. Upachara viruddha (contrary to observances)

14. Paka viruddha (contrary to cooking)

15. Samyoga viruddha (contrary to combination)

16. Hridaya viruddha (contrary to palatability)

17. Sampata viruddha (contrary to rich quality)

18. Vidhi viruddha (contrary to mealtime rules) ${ }^{2}$

\section{Few contradictory combination are:}

1. Fish or its soup along with milk.

2. Equal quantity of honey with ghee.

3. Milk or milk products with alcoholic beverages.

4. Processed food or cereals with milk.

5. Radish consumed with milk.

6. Lotus stem with honey etc. ${ }^{3}$

\section{Forbidden food articles}

There are some dietary articles which are unwholesome by nature cause illness and their excessive or regular intake is be contraindicated and prohibited. Excessive consumption of Pippali (Piper longum) leads to disorder of homeostasis of physiology and over intake of Lavana (common salt) can cause premature greying of hair, falling of hair, alopecia, wrinkles of the skin and excessive intake of alkaline foods are harmful for eyes, hair and heart diminished vision, premature greying of hair, falling of hair. ${ }^{2}$ 
Prophylactic and therapeutic aspects of ayurvedic dietetics

Biological activity and Nutritional effect of different tastes of food: The food comprises of six basic tastes viz. madhura (sweet), amla (sour), lavana (salt), katu (pungent), tikta (bitter), kashaya (astringent) and each taste have specific impact on bio-humours and tissue function. Ayurvedic advocacy at all times emphasizes on enjoying all six tastes of food and prohibition of excessive use of single tastes leading to illness. Moreover different tastes provide specific biological activity influencing physiology and nutritional impact. $(\text { Table } 3)^{5}$

Table 3: Biological activity and Nutritional effect of different tastes of food

\begin{tabular}{|c|l|l|l|}
\hline S No. & \multicolumn{1}{|c|}{ Taste } & \multicolumn{1}{|c|}{ Metabolic Impact } \\
\hline 1. & Sweet (Madhura) & $\begin{array}{l}\text { Tissue nourishing; Bulk promoting hair tonic ; Injury healing; } \\
\text { Galactogogue }\end{array}$ \\
\hline 2. & Sour (Amla) & $\begin{array}{l}\text { Nourishing; Bulk promoting; Cardio-protective; increases taste and power } \\
\text { of digestion. }\end{array}$ \\
\hline 3. & Astringent (Kashay) & Injury relieving; clarifies blood. \\
\hline 4 & Salty taste (Lavana) & $\begin{array}{l}\text { Pulls down Inactivity; Inertness; accelerates digestion; leads to } \\
\text { Unctuousness and causes perspiration; accelerates taste. }\end{array}$ \\
\hline 5. & Bitter taste (Tikta) & $\begin{array}{l}\text { It vitiates Loss of appetite, Worms, Thirst, Toxicity, Skin ailments, } \\
\text { Fainting, Fever, Over secretion of mucous, Burning sensation; It regulates } \\
\text { Intellect; clarifies Breast milk; and Throat }\end{array}$ \\
\hline 6. & Acrid taste (katu) & $\begin{array}{l}\text { Vitiates Throat ailments; Skin diseases; Oedema; Increases digestibility; } \\
\text { Improves appetite (3) }\end{array}$ \\
\hline
\end{tabular}

\section{Prophylactic Nutrition Intervention in Paediatrics}

Ayurveda emphasized initial importance on wholesome diet (prophylactic and promotive nutrition) while advocacy of specific diet in disease condition (clinical nutrition) is always done, which is the characteristic of holistic Ayurvedic approach. (Table 4) ${ }^{6}$

Table 4: Prophylactic Nutrition Intervention in Pediatrics

\begin{tabular}{|c|c|c|c|}
\hline S. No. & Age & Nutritional Interventions & Rationale \\
\hline 1. & $\begin{array}{l}\text { Immediately } \\
\text { after birth }\end{array}$ & $\begin{array}{l}\text { Jata karma - Chanting the mixture } \\
\text { Honey and Ghee }\end{array}$ & Immune mechanism \\
\hline 2. & $\begin{array}{l}\text { Immediately } \\
\text { after birth }\end{array}$ & $\begin{array}{l}\text { Swarna prashana - Oral intake of fine } \\
\text { paste of Gold }\end{array}$ & Immunity, Intelligence \\
\hline 3. & $\begin{array}{l}\text { Immediately } \\
\text { after birth }\end{array}$ & $\begin{array}{l}\text { Bacopa monnieri , Acorus calamus, } \\
\text { Convolvulus pluricaulis Sida cordifolia, } \\
\text { Saussurea lappa, Asparagus racemosus }\end{array}$ & Immunity, Intelligence, Energy etc. \\
\hline 4. & $1^{\text {st }}$ day & $\begin{array}{l}\text { Honey+ Butter+ Hemidesmus indicus, } \\
\text { Cynadon dactylon /Gold }\end{array}$ & $\begin{array}{l}\text { Promote Higher Mental Functions and } \\
\text { CNS }\end{array}$ \\
\hline 5. & 2nd day & Ghee medicated with Herbs & $\begin{array}{l}\text { Promote Higher Mental Functions and } \\
\text { CNS }\end{array}$ \\
\hline 6. & 3rd day & $\begin{array}{l}\text { Colostrum of breast milk }+ \text { Ghee }+ \\
\text { Honey }\end{array}$ & $\begin{array}{l}\text { Promote Higher Mental Functions and } \\
\text { CNS }\end{array}$ \\
\hline 7. & $\begin{array}{l}1 \text { st month or } \\
\text { 3rd month }\end{array}$ & $\begin{array}{l}\text { Surya Chandra Darshana :Exposure to } \\
\text { external environment }\end{array}$ & Vitamin - D3 or Hepatic function \\
\hline 8. & 6th month & $\begin{array}{l}\text { Phalaprashana: Introduce different } \\
\text { Fruits }\end{array}$ & Fulfilment of Nutritional demand \\
\hline 9. & 10th month & $\begin{array}{l}\text { Annaprashana: Introduce variety of } \\
\text { cereals and pulses in the diet of the child }\end{array}$ & Fulfilment of Nutritional demand(3) \\
\hline
\end{tabular}

\section{Disease specific diet}

Ayurveda provides the pathyavyavastha (planning of diet- dietetics) in a very scientific and holistic way Pathya (or a proper diet advocacy) is defined as the "diet plan". The recipes for clinical nutrition portrays several form of diets with clinical properties. These approaches certainly play a vital role in prevention and management of diseases. $(\text { Table-5 })^{8}$ 
Table 5: Disease specific diet

\begin{tabular}{|c|c|c|}
\hline Diseases & Nutritional Causes & Management \\
\hline $\begin{array}{l}\text { Diabetes } \\
\text { (Madhumeha) }\end{array}$ & $\begin{array}{l}\text { Excessive intake of Milk \& Milk products, } \\
\text { Fresh grains, Food articles prepared from } \\
\text { Jaggery or Sugar or } \\
\text { Sugar cane }\end{array}$ & $\begin{array}{l}\text { Barley, Old wheat, Horse gram, Green } \\
\text { gram, Red gram, Sesame seeds, Peas, } \\
\text { Snake gourd, Bitter gourd, Garlic, } \\
\text { Ginger, Piper longum, unripe Banana, } \\
\text { Takra (butter milk), Kharjur (dates), } \\
\text { Water melon, Lotus root, Drum stick }\end{array}$ \\
\hline $\begin{array}{l}\text { Skin diseases } \\
(\text { Kushta) }\end{array}$ & $\begin{array}{l}\text { Consumption of uncooked food, over eating, } \\
\text { over intake of fresh grains, sour and salty } \\
\text { substances, Black gram, Raddish, Sesame } \\
\text { seeds, Milk and Milk products, Jaggery. }\end{array}$ & $\begin{array}{l}\text { Old barley, Wheat, Green gram, Red } \\
\text { gram, Old ghee, Honey, Pointed gourd, } \\
\text { Garlic, Oil of Sesame, Mustard etc. }\end{array}$ \\
\hline $\begin{array}{l}\text { Abdominal } \\
\text { disorders } \\
\text { (Udara roga) }\end{array}$ & $\begin{array}{l}\text { Use of adulterated and uncooked food, stale } \\
\text { food items, leafy vegetables, incompatible } \\
\text { food, and foods causing Indigestion \& } \\
\text { Constipation. }\end{array}$ & $\begin{array}{l}\text { Old horse gram, Green gram, Barley, } \\
\text { Honey, Butter Milk, Garlic,Ginger, } \\
\text { Castor oil, Pointed gourd (parval), Bitter } \\
\text { gourd, Drum stick, Cow's \& goat's milk }\end{array}$ \\
\hline $\begin{array}{l}\text { Haemorrhoids } \\
\text { (Arsha) }\end{array}$ & $\begin{array}{l}\text { Intake of dry food articles causing } \\
\text { Constipation; Fish, paste of Sesame seeds, } \\
\text { Black gram, ripe Mango, Soft gourd. }\end{array}$ & $\begin{array}{l}\text { Red variety of rice, Butter milk, Butter, } \\
\text { Goose berry, Black pepper, Pointed } \\
\text { gourd, Cow's milk, Goat's milk, Rice } \\
\text { gruel, Garlic, Ginger, Haritaki, Mustard } \\
\text { oil etc }\end{array}$ \\
\hline $\begin{array}{l}\text { Diseases related } \\
\text { to nervous } \\
\text { system } \\
\text { (Vata vyadhi) }\end{array}$ & $\begin{array}{l}\text { Dry, cold, scanty food, fasting or starvation, } \\
\text { over intake of Honey, Peas, Green gram }\end{array}$ & $\begin{array}{l}\text { Food containing sufficient fat content, } \\
\text { easily digestible, warm food, Wheat, } \\
\text { Horse gram, Black gram, Brinjal, milk. }\end{array}$ \\
\hline $\begin{array}{l}\text { Fistula - in-ano } \\
\text { (Bhagandara) }\end{array}$ & $\begin{array}{l}\text { Consumption of dry food articles leading to } \\
\text { Constipation. }\end{array}$ & $\begin{array}{l}\text { Red variety of rice, Green gram, Pointed } \\
\text { gourd, Drum stick, Radish, Sesame and } \\
\text { Mustard oil, Ghee, honey etc }\end{array}$ \\
\hline $\begin{array}{l}\text { Urinary calculus } \\
\text { (Asmari) }\end{array}$ & $\begin{array}{l}\text { Consumption of sour and dry food articles } \\
\text { aggravate Constipation, Incompatible food. }\end{array}$ & $\begin{array}{l}\text { Barley, Horse gram, Old rice, Madya, } \\
\text { Ginger etc }\end{array}$ \\
\hline $\begin{array}{l}\text { Oedema } \\
(\text { Sopha })\end{array}$ & $\begin{array}{l}\text { Intake of excessive sour, hot or Alkaline } \\
\text { food, foods hard to digest, Curd, Uncooked } \\
\text { food, Leafy vegetables, Stale and } \\
\text { Adulterated (poisoned) food, Alcohol. }\end{array}$ & $\begin{array}{l}\text { Barley, Horse gram, Green gram, Fish, } \\
\text { Old ghee, Butter milk, Bitter gourd, } \\
\text { Drum stick, Mango, Carrot, Pointed } \\
\text { gourd, Brinjal, Radish, Turmeric, Milk. }\end{array}$ \\
\hline
\end{tabular}

Prevention of Sequential loss of several biological qualities in aging: Suggested Ayurvedic Nutritional approach: Ayurvedic nutritional approach and various interventions for prevention of sequential loss of some biological qualities in aging are described in Table 6.

Table 6: Prevention of Sequential loss of several biological qualities in aging: Suggested Ayurvedic Nutritional approach

\begin{tabular}{|l|c|l|l|}
\hline \multicolumn{1}{|c|}{ Decades } & \multicolumn{1}{c|}{ Age } & \multicolumn{1}{c|}{ Desired effect } & $\begin{array}{l}\text { Suggested interventions for prevention of } \\
\text { sequential loss of several biological qualities }\end{array}$ \\
\hline First & $0-10$ & Balya (Boyishness) & $\begin{array}{l}\text { Vaca (Acorus calamus } \text { Linn.) } \\
\text { Kasmari (Gmelina arborea } \text { Linn.) }\end{array}$ \\
\hline Second & $11-20$ & Vriddhi (Growth) & $\begin{array}{l}\text { Asvagandha (Withania somnifera) } \\
\text { Bala (Sida cordifolia } \text { Linn.) }\end{array}$ \\
\hline Third & $21-30$ & Chhavi (Beauty) & Amalaki (Emblica officinalis Gaertn.) \\
\hline Fourth & $31-40$ & Medha (Intellect) & $\begin{array}{l}\text { Sankhapushpi(Convolvulus pluricaulis) } \\
\text { Jyotismati (Celastrus panniculatus } \text { ) }\end{array}$ \\
\hline Fifth & $41-50$ & Twacha (Skin health $)$ & Bhringaraja (Eclipta alba Hassk) \\
\hline Sixth & $51-60$ & Dristi (Visual acuity ) & Caksusya (Cassia absus Linn.) \\
\hline
\end{tabular}




\begin{tabular}{|l|l|l|l|}
\hline Seventh & $61-70$ & Sukra (Sexual Ability) & $\begin{array}{l}\text { Triphala,Ghee) } \\
\text { Atmagupta (Mucuna prurita Hook) } \\
\text { Asvagandha (Withania somnifera) }\end{array}$ \\
\hline Eighth & $71-80$ & $\begin{array}{l}\text { Vikram } \\
\text { endurance ) }\end{array}$ & $\begin{array}{l}\text { Understandable rasayana interventions to } \\
\text { improve physical and psychological quality of } \\
\text { life (QOL) }\end{array}$ \\
\hline Ninth & $81-90$ & $\begin{array}{l}\text { Buddhi (Mental health and } \\
\text { wisdom }\end{array}$ & $\begin{array}{l}\text { Knowable rasayana interventions to improve } \\
\text { physical and psychological quality of life } \\
\text { (QOL) }\end{array}$ \\
\hline Tenth & $91-100$ & $\begin{array}{l}\text { Karmendriya } \\
\text { (Motor Activity) }\end{array}$ & \\
\hline
\end{tabular}

Modernity of food: Today's diet is drastically different from that of just 30 or 40 years ago. Then most food was fresh, grown locally, recent, sound and cooked at home. Now, almost everything we purchase has been processed. It comes with additives, chemicals, colourings, sugar, trans fats and salt or sodium, white flour.

As the speed of our society has quickened, more and more people are eating on the go. They are picking up fried, fast food and eating it in the car, they are grabbing pre-packaged snacks and drinks and they are eating foods that are not made fresh or naturally. Following the evolution of modern human, another vast change in diet occurred due to manufacturing technologies developed after the industrial revolution.

\section{Relates to junk food}

Modern diet relates to "junk food" that generally means an empty calorie food. An empty calorie food is a high calorie or calorie-rich food which is deficient in micronutrients such as carbohydrates, proteins, vitamins, minerals, or amino acids and fibre, but has high energy (calories). These foods are made of high levels of refined sugar, white flour, trans fat, poly unsaturated fat, salt and various food additives such as monosodium glutamate, tartrazine, at the same time it is lacking in proteins, vitamins, essential minerals, fibres.

The numerous food systems and diets that are part of these diverse ways of life affecting people's levels of physical activity, their body composition \& physique, their life expectancy, and patterns of diseases. ${ }^{7}$ A case study on consumption of fast foods in Ghana reported a direct correlation between intake of junk food and obesity rates.

The report suggests that obesity resulted in related complex health concer ns such upsurge of heart attack rates. A Scripes Research Institute study in 2008 confirmed that junk food consumption alters brain activity in a manner similar to addictive drugs like cochaine and heroin.

Rapid changes in diet and lifestyle led to a vast emerging shift towards non-communicable diseases (NCDs) such as lifestyle related disorders (diabetes, obesity, arthritis, mental illness, cardiac diseases, cancer etc.) and Ayurvedic principles certainly play a vital role in their prevention and management. ${ }^{3}$

\section{Conclusion}

The evolutionary history of hominins has been characterized by major dietary changes, which include the introduction of meat eating, cooking, and the changes associated with plant and animal domestication. Decades of anthropological research have been devoted to elucidating this dietary history, in part because these shifts were likely associated with significant anatomical and cultural changes (e.g., the increase in relative brain size and the advent of modern civilization via agriculture). However, this reconstruction is also vital for understanding the evolutionary context of our modern diets and the diseases often associated with them. Rapid changes in diet and lifestyle led to a major emerging shift towards non-communicable diseases which are responsible for recent useless food. So, to survive from such vicious condition, we have to take our coumtry's traditional ayurvedic system which deals with health-promoting regime (pathya vyavastha); specific diet and lifestyle guidelines are always recommended along with the drugs and therapies. Therefore, significant emphasis on diet planning based on Ayurveda principles would certainly help in health promotion, prevention of diseases and their management.

Several research papers have been published substantiating the potential of Ayurvedic interventions in malnutrition and developing physical endurance and health promotion in children and adults. Ayurveda has considered human dietetics and nutrion not only from the view of physical hygiene but also mental and and social hygiene by deeply thinking of surrounding environmental and social conditions and hence, it is certainly applicable to the modern world. Thus, Ayurveda proposes an entirely different approach to food, diet, and nutrition that is in strong contrast to the conventional Western and modern approach.

\section{References}

1. Nishteswar K. Ayurvedic Concept of Food and Nutrition. $J$ Nutr Food Sci 2016;6:530. doi:10.4172/21559600.1000530)

2. (http://creativecommons.org/licenses/by/4.0/), doi:10.1017/S0007114516001598

3. www.wjpps.com, Tewari et al.3

4. http://journalofethnicfoods.net 
5. Payyappallimana U and Venkatasubramanian P. Exploring Ayurvedic Knowledge on Food and Health for Providing Innovative Solutions to Contemporary Healthcare. Front. Public Health 2016;4:57. doi: 10.3389/fpubh.2016.00057)

6. Satyapal Singh "Principle and Practice of Nutrition and Dietetics in Ayurveda"
7. NIH Public Access, Author Manuscript. Annu Rev Nutr 2010;30:291-314. doi:10.1146/annurev- nutr-080508141048 .

8. Payyappallimana U and Venkatasubramanian P. Exploring Ayurvedic Knowledge on Food and Health for Providing Innovative Solutions to Contemporary Healthcare. Front. Public Health 2016;4:57. doi: 10.3389/fpubh.2016.00057 